\title{
WHY WE HAVE NO SERIOUS ALTERNATIVES BUT COOPERATIVE TAXONOMY
}

\author{
Franco Pupulin \\ Lankester Botanical Garden, University of Costa Rica \\ Harvard University Herbaria, Cambridge, Massachusetts, U.S.A. \\ The Marie Selby Botanical Gardens, Sarasota, Florida, U.S.A \\ franco.pupulin@ucr.ac.cr
}

\begin{abstract}
Taxonomic work has been historically regarded as a two-fold discipline. The first, which is basically aimed at answering the question about the diversity in whatever group under study, includes most of the "biological" questions of the research. Understanding of genetic and morphological variation, structure of populations and life cycles, biogeography and phylogeography, ecological modeling, pollination and other biological components is required to define the relationships among the taxa of the group and eventually to describe their diversity. The second part of the work consists in applying a correct name to all of the organisms as they result from the biological work. This second step is usually interpreted as the documentary component of the research, and in fact it mostly deals with the document sources and the rules of biological nomenclature (such as protologues, types and other historical materials associated with the type collections, etc.). However, the use of nomenclatural sources with little or no consideration for the biological aspects of the concerned organisms can be misleading, and the same concept of "type" can be hardly understood if not framed in a rich biological context. Type specimens are just random, individual samples that must be interpreted in the context of the geographical and biological integrity of any given species, and this requires at least some direct knowledge of the organisms and their biology. When the geographical origin of type specimens lies outside the political boundaries of a given study area, taxonomic research is seriously hampered by the impossibility to visualize and understand them in a biological framework. A specific case from the research intended to complete the treatment of the Orchidaceae for the flora of Costa Rica will exemplify how a cooperative approach based on a shared methodology may be the only way to resolve the taxonomy of complex species.
\end{abstract}

RESUMEN. El trabajo taxonómico ha sido históricamente considerado como una disciplina doble. Por un lado, su objetivo fundamental es responder a la pregunta sobre la diversidad de cualquier grupo bajo estudio, y esto incluye la mayoría de las preguntas "biológicas" de la investigación. Para entender las relaciones y parentescos entre los taxones de un determinado grupo, y finalmente describir su diversidad, se requiere de la comprensión de la variación genética y morfológica, de la estructura de las poblaciones y sus ciclos de vida, de la bio- y filogeografía, de los modelos ecológicos, así como de la polinización y otros componentes bióticos que interactúan con los taxones en estudio. La segunda parte del trabajo consiste en la aplicación de un nombre correcto a cada uno de los organismos así como resultan identificados a través de al etapa biológica del estudio. Esta segunda etapa se interpreta usualmente como la componente documentaria de la investigación, y de hecho tienen mayormente que ver con las fuentes documentales y las reglas de la nomenclatura biológica (tales como protólogos, tipos y otros materiales históricos asociados con las recolectas-tipo, etc.). Sin embargo, el uso de fuentes de nomenclatura asociados a poca o ninguna consideración de los aspectos biológicos de los organismos en estudio puede ser engañoso y el mismo concepto de "tipo" puede difícilmente entenderse si no está enmarcado en un contexto biológico complejo. Los especímenes tipo no son sino ejemplos individuales escogidos al azar, los cuales deben ser interpretados a la luz de la integridad biológica y geográfica de una especie determinada, y esto requiere de por lo menos de algún tipo de conocimiento directo de los organismos y su biología. Cuando el origen geográfico de los especímenes tipo se encuentra afuera de los límites políticos de una determinada área 
de estudio, la investigación taxonómica se encuentra seriamente impedida por la imposibilidad de visualizar y entender los tipos en un marco biológico. Un ejemplo del trabajo finalizado a completar el tratamiento de Orchidaceae para la flora de Costa Rica puede enseñar como solamente un acercamiento cooperativo, basado en una metodología común, puede resolver la taxonomía de especies complejas.

KEY wORDS: cooperative research, identification, interpretation of types, taxonomy

Introduction. As the branch of science specifically concerned with the description, identification, naming, and classification of organisms, taxonomy has been historically regarded as a two-fold discipline (de Jong 1982). The Greek etymology of the name of the discipline is, in itself, a symptom of this duality. Although there is no ambiguity about the meaning of the ancient Greek word $\tau \alpha \dot{\xi} \xi 1 \zeta$, taxis, "arrangement, division", the etymology of the second root of the term taxonomy has been referred to both the Greek -vónos -nomos, "law", and -vouía -nomia, "method". Even if subtle, the emphasis in the first case is on the orderly classification of organisms according to their presumed evolutionary relationships, whereas in the latter it stresses the main scope of the science at providing an arrangement according to any pre-determined system (a method of classification) to provide a conceptual framework for discussion, analysis, and information retrieval.

The first part of the taxonomic work is indeed aimed at answering the fundamental question about the diversity in the group under study. This activity is still particularly relevant in exploring diversity in the highly biodiverse regions of the planet, where the inventory of life forms is far from complete and more necessary than ever for effective decision-making about conservation and sustainable use. Recent estimates indicate that only $10-20 \%$ of living organisms have been discovered/described/catalogued?, the remaining biodiversity numbering perhaps eight million or more species (Wilson 2003). The existence of a taxonomic impediment to the sound management of biodiversity has been already acknowledged by most governments through the Convention on Biological Diversity and the development of the Global Taxonomy Initiative, aimed at reducing the negative effects of insufficient scientific knowledge of life's diversity (Anonymous 1998a, 1998b, Graham 2005). The core missions of alphataxonomy, i.e. detecting, identifying, and describing biodiversity units, and supporting these hypotheses with data remain fundamental to all of biology and must be made widely available to address questions outside of taxonomy (Deans et al. 2012), even though this simple truth is rarely taken into account by the agendas of institutions and financing agencies (Flowers 2007). Fundamental questions from other disciplines such as speciation, diversification processes, ecosystem development, and conservation priorities depend on correct species boundaries and diversity estimates (Dayrat 2005, Padial et al. 2010). From its beginnings, by using the phenotype, taxonomy has progressed with the continuous use of different tools, evolving enough to enable a better understanding of how genes control morphology today. In order to provide crucial data on ecology, evolution, and biogeography, and a rational framework for phylogenetic and phylogeographic studies, "modern" taxonomy (whatever this frequently used expression means) requires intensive collecting and observation, detailed measurement, description, and illustration, as well as information at the cellular and molecular levels (Bicudo 2004).

It is true that merely collecting and describing new species does not advance our understanding of life (Ehrlich 1961), but it has to be remembered that the process of describing life's diversity is fundamentally aimed at identifying species, not specimens (Dick \& Mawatari 2004). As such, taxonomy deals with groups of individuals (specimens) that show, to a greater or lesser degree, intraspecific variability. The understanding of the morphology and evolution of a particular group, which is expressed in polymorphism and natural phenotypic variability, is essential to define the relationships among the taxa of the group and eventually describe their real diversity. It cannot be stressed enough how a reliable taxonomy must be an information-intensive field, which requires not only a firsthand knowledge of a large sample of populations and individuals belonging to the concerned groups, but also information on the key characters driving the evolution of a particular group, the training in interpreting centuries of previous literature, as well as a comparative understanding of the past and present schemes of classification. 
Even though the floras of bio-rich tropical countries were mostly made by scientists working and studying outside the natural environments of the concerned taxa, it is today broadly recognized that modern floristics require appreciation of natural variation (Ellison et al. 2014), so relying on the fine comparison of broadly sampled specimens cannot be carried out without a local school of trained botanists. Such an approach produces useful classification systems more easily, which allow the delimitation and identification of species in such a way that they exhibit genetic differences and ecological preferences (McNeill 1976). A great familiarity with local geography, the appreciation of the taxonomic implications of fine-tuned ecological mapping, direct knowledge of the historical background of botanical exploration, and ample access to the examination of both living and pressed specimens greatly improve the accuracy and reliability of floristic catalogues, identification of critical materials, description of new taxa, and formulation of hypotheses on evolutionary relationships among living organisms.

For as accurate as it might be, the detection and identification of the diversity of living organisms in a given region represents only the first step along the path aimed to produce a catalogue of life. This catalogue, in fact, requires the correct naming of the retrieved organisms and groups, both at the specific level and at the supra- and infra-specific categories. The diversity of life on Earth can neither be appreciated nor communicated without a semantic system that can name it in a consistent and repeatable way (Patterson et al. 2010). Nomenclature is the second essential element of taxonomy. It is governed by a set of rules that date back to the lois de Candolle in 1867 (de Candolle 1867), through the "Vienna Rules" of 1906 (Briquet et al. 1906) and the "Stockholm Code" of 1952, and has been since continuously updated and adapted to the new needs of science up to the recent Melbourne Code, adopted in 2011 (McNeill et al. 2011).

One of the crucial rules of the Code is that the name of a taxon is permanently attached to "a nomenclatural type (typus)" (McNeill et al. 2011: art. 7). The typus is an example that serves to anchor the defining features of that particular species and a reference point when attempting to determine the correct application of a name.

Tropical botany (and orchidology is not an exception) has been traditionally hampered by the difficulty to access type specimens for comparison and application of names, as most of the types were kept in European and North American herbaria and museums. To circumvent the difficulty of accessing, and the delicacy of conserving, historical specimens, images of types in the form of photographs, slides, photocopies, etc. have been used as complementary materials for taxonomic studies, but it was not until the advent of digital data capture in the last few decades that the information sources represented by biological collections kept in developed countries began to be disseminated effectively (Pupulin 2013). Today, the use of the Internet and the increasing availability both of digitized historical literature and images of plant types from all the major herbaria around the world have amplified visual access to the most important sources of nomenclatural concepts. The Global Plants Initiative, an international undertaking by leading herbaria to digitize and make types available, includes more than 270 partners in 70 countries and holds nearly two million high-resolution images of plant type specimens (La Monica 2013). Although such images offer the advantage of their instantaneous accessibility, the examination of the actual specimens is still considered the preferred method for several types of scientific research, because critical features may be difficult to discern from two-dimensional images (Culley 2013). There is, however, an additional argument to be discussed relative to the study and understanding of plant type specimens.

\section{A biological approach to type specimens and species} concepts. Type specimens are random individuals from a given population, randomly collected and designated as a reference to fix the combination of key and unique features associated with that particular species concept. As such, types represent only one point within a continuum of genetic and morphological differences among members of the same species, as well as across its entire geographic range, and not necessarily the most representative element of its own taxon. Understanding the extent of natural variation among individuals or populations of a single species is a fundamental task for the botanist. Correct interpretation of nomenclatural types gives the botanist the ability to assign individuals to groups using clear phenotypic distinctions that (may or may not) reveal 
underlying genetic differences (Mather \& Jinks 1982) and ensures that the material which typically corresponds to that species falls within the continuous range of variation provided by their descriptions.

Variation in plant morphology could be, on the other hand, a function of phenotypic responses to selection pressures and thus reflect the evolutionary history of populations. Several morphological features are genetically constrained but also greatly affected by the specific conditions of the environment in which they develop (Ellison et al. 2004). In order to understand if morphological variation is associated with environmental and climatic gradients, the expected geographic range of a species must be known, and a broad sampling of individuals is required, including specimens sympatric with the type as well as individuals from disjunct populations. Genetic sampling, including a broad representation of individuals from distinct populations and possibly specimens from the type localities, accompanied by a rigorous record of individual salient features, would also immensely help in assessing univocal species circumscriptions. Genetic characterization should ideally be done locally according to shared protocols, in order to circumvent the growing difficulties in moving samples across political boundaries for molecular analyses.

In any of these scenarios, an exhaustive survey and a precise documentation of individual variation, or phenome annotations, at the type locality are required for the correct interpretation and unambiguous understanding of the type specimen. Next-generation sequencing (NGS) promises to be of major utility for the study of herbarium specimens, including types. Most NGS methods are designed for using as templates short fragmented DNA molecules, and the recovering of entire nuclear genomes from old herbarium specimens has already been carried out with success (Straub et al. 2012, Staats et al. 2013). Only a rich biological approach, which takes into account complementary perspectives - phytogeography and phylogeography, genetics, pollination ecology, among others -guarantees that the boundaries of a given species can be accurately traced from the study of the type. As plant distribution is irrespective of political boundaries, it is frequent in taxonomic research that the type locality lies outside the study region.
The drawback of the integrative approach is that it can be carried out only at the local level, where populations at the type locality or close to it still exist and may be sampled for critical study. The advantage of the method, however, is that it requires training and involvement in the research for local students, who must possess the phytogeographic, ecological, and taxonomic skills required to document intraand interspecific variation and compare it with the set of individual features that are specific to the type specimens.

A closer look at a specific case may clearly exemplify the need of a cooperative approach to the interpretation of the types and to a sound application of names.

The enigmatic tailed Brassia. Brassia caudata (L.) Lindl. has been treated as the most widespread species of the genus, including records from the whole of tropical America. It has been recorded from Florida, Jamaica, Cuba, the Dominican Republic and Haiti, Trinidad, Mexico, Guatemala, Belize, El Salvador, Nicaragua, Costa Rica, Panama, Venezuela, Surinam, Guyana, Brazil, Colombia, Ecuador, Peru, and Bolivia (Cogniaux 1906, Fawcett \& Rendle 1910, Williams \& Allen 1946, Ames \& Correll 1953, Foster 1958, Schultes 1960, Schweinfurth 1961, Dunsterville \& Garay 1966, Foldats 1970, Long \& Lakela 1971, Hamer 1974, Dressler 1980, Hamer 1982, Vásquez \& Dodson 1982, Breedlove 1986, Werkhoven 1986, Dodson \& Bennett 1989, Atwood \& Mora de Retana 1993, Brako \& Zarucchi 1993, Dodson 1993, Dressler 1993 , Bennett \& Christenson 1995, Gloudon \& Tobisch 1995, McLeish et al. 1995, Steyermark et al. 1995, Wunderlin 1998, Jørgensen \& León-Yánez 1999, Balick et al. 2000, Nir 2000, Carnevali et al. 2001, Martínez et al. 2001, Stevens et al. 2001, Fernández 2003, Dodson \& Luer 2005, Llamacho \& Larramendi 2005, Pupulin 2005, Misas Urreta 2006, Fernández 2007, Ospina H. 2008, Zelenko \& Bermúdez 2009, Luz \& Franco 2012, Rakosy et al. 2013). Morphologically, these records are highly variable, sharing basically the caudate lateral sepals, a common and probably plesiomorphic feature in the genus (Fig. 1). In Costa Rica, at least two taxonomic entities broadly distinct on the ground of geographic distribution, morphological features, and fragrance (Fig. 2-3), have been treated as members 


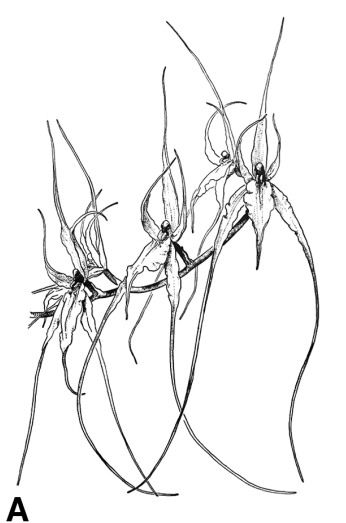

A
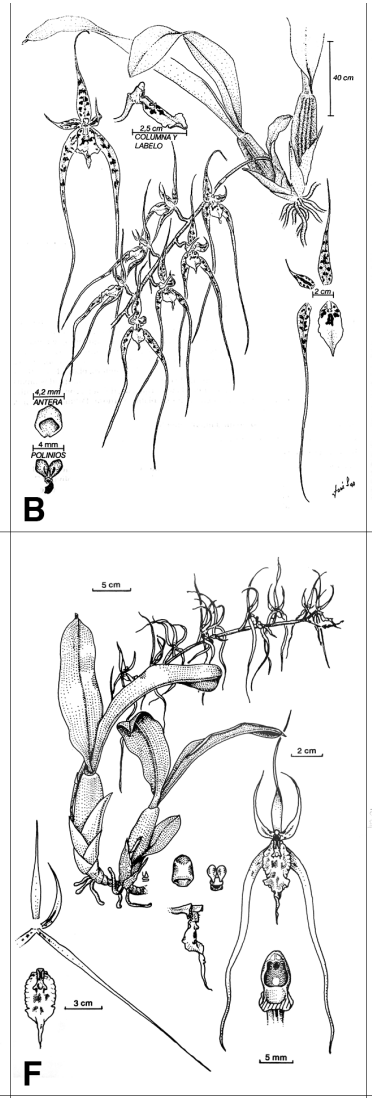

E

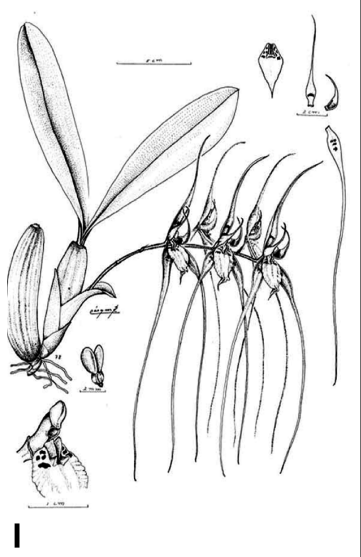

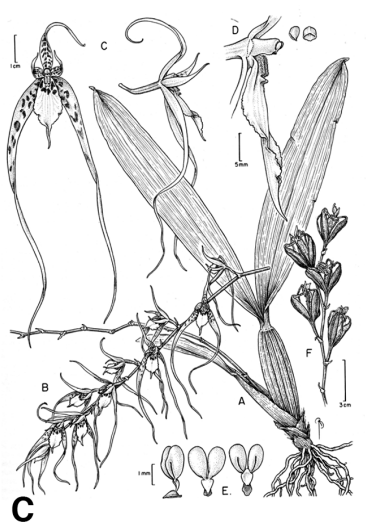

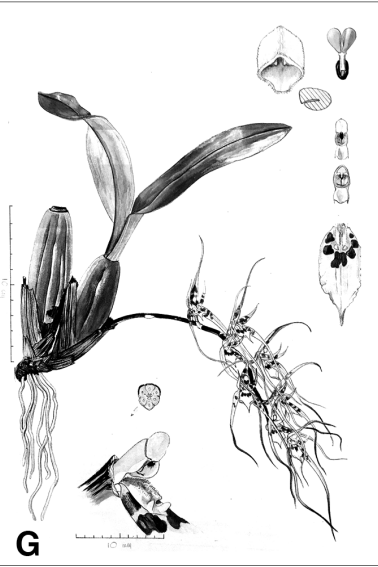

D
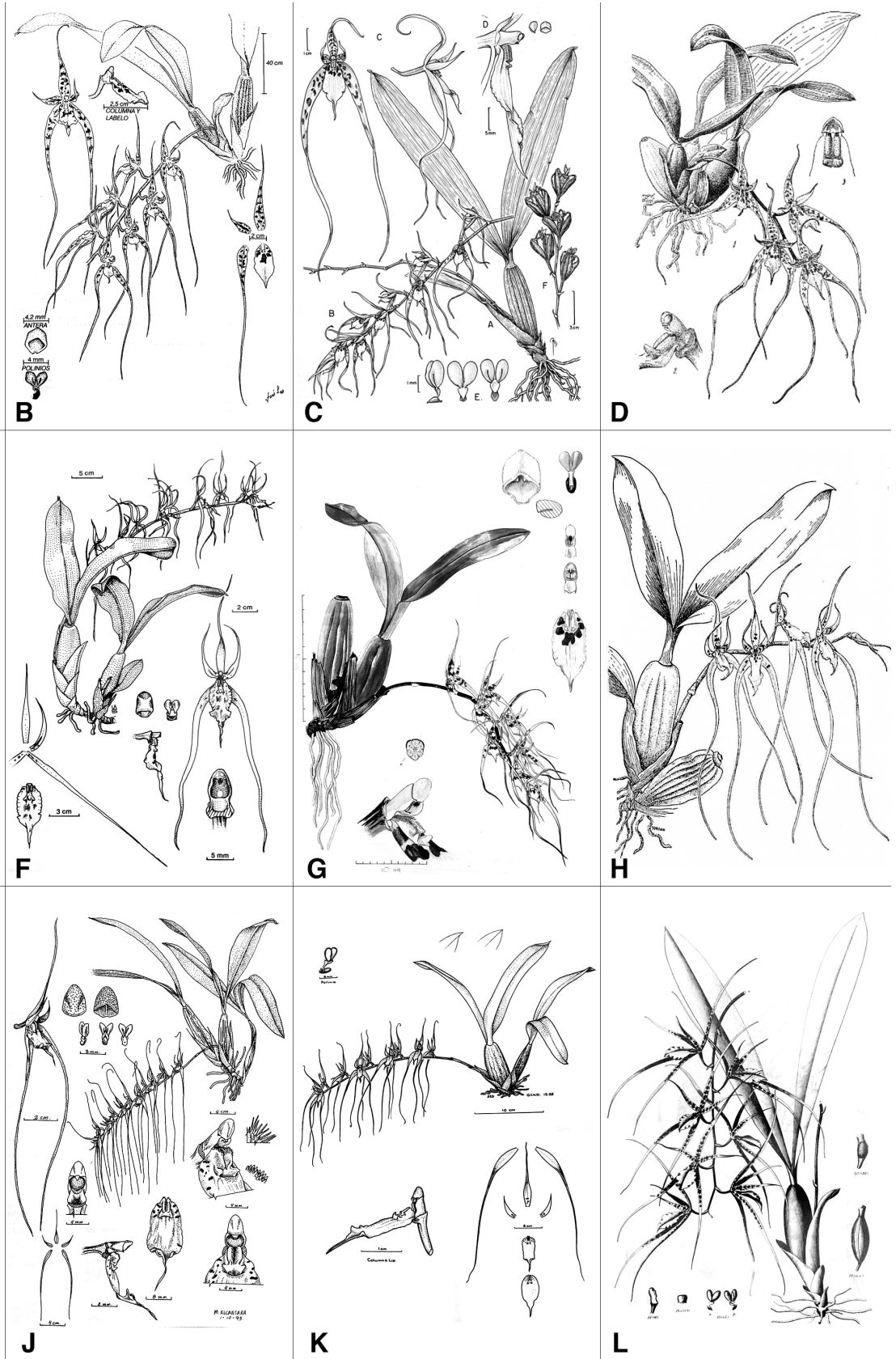

H

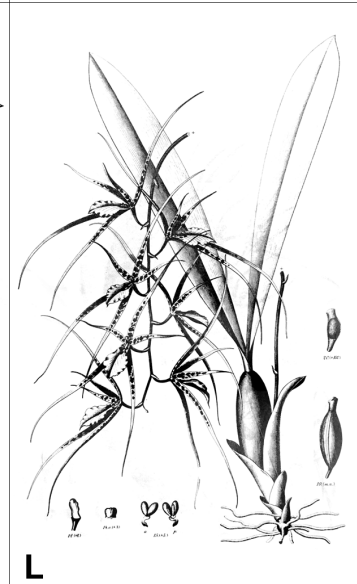

FigURE 1. Illustrations from specimens identified as Brassia caudata from different regions. A, Florida (from Ames 1947). B, Cuba (from Mújica Benítez et al. 2000). C, Cuba and Jamaica (composite plate from Ackerman 2015). D, Guatemala (from Ames \& Correll 1953). E, Nicaragua (from Hamer 1982). F-G, Costa Rica (from Atwood \& Mora 1993, and Rodríguez Caballero et al. 1986, respectively). H, Panama (from Williams \& Allen 1946). I, Colombia (from Escobar R., 1990). J, Peru (from Bennett \& Christenson 1995). K, Venezuela (from Dunsterville \& Garay 1966). L, Brazil (From Cogniaux 1906). 


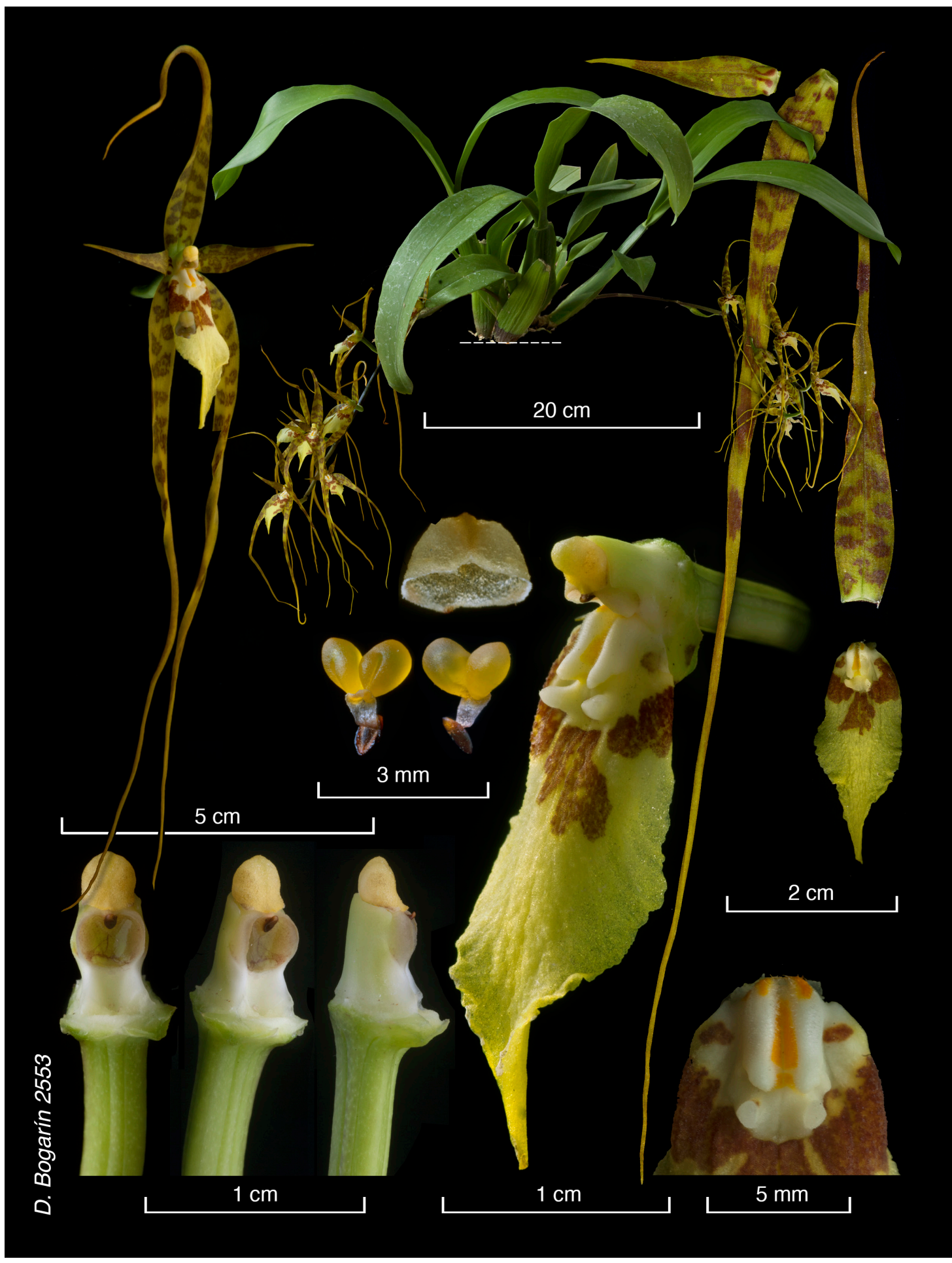

Figure 2. Lankester Composite Digital Plate of Brassia cf. caudata. Costa Rica, Caribbean morph, D. Bogarín 2553 (voucher: JBL). 


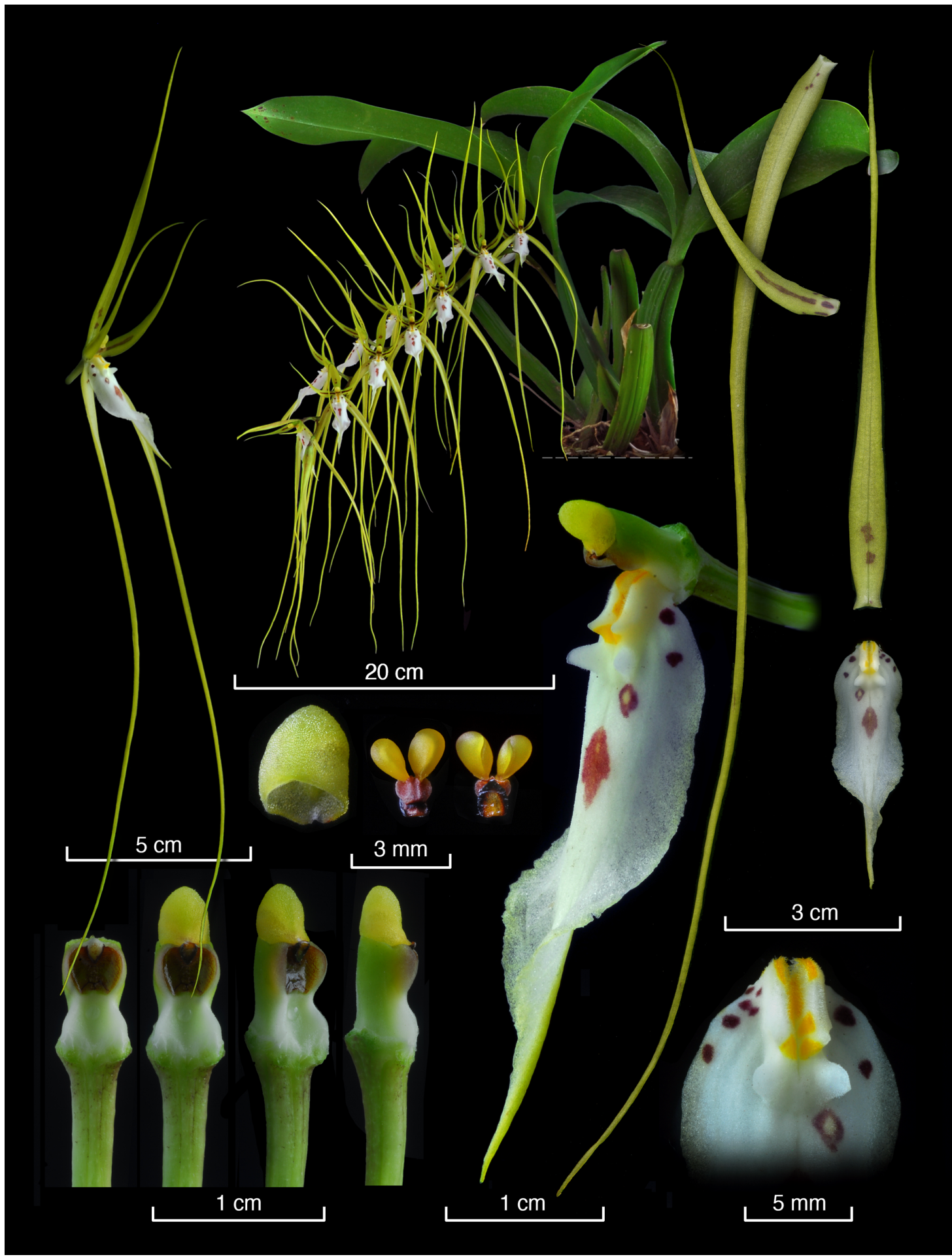

Figure 3. Lankester Composite Digital Plate of Brassia cf. caudata. Costa Rica, Pacific morph, JBL-21704 (voucher: JBL). 


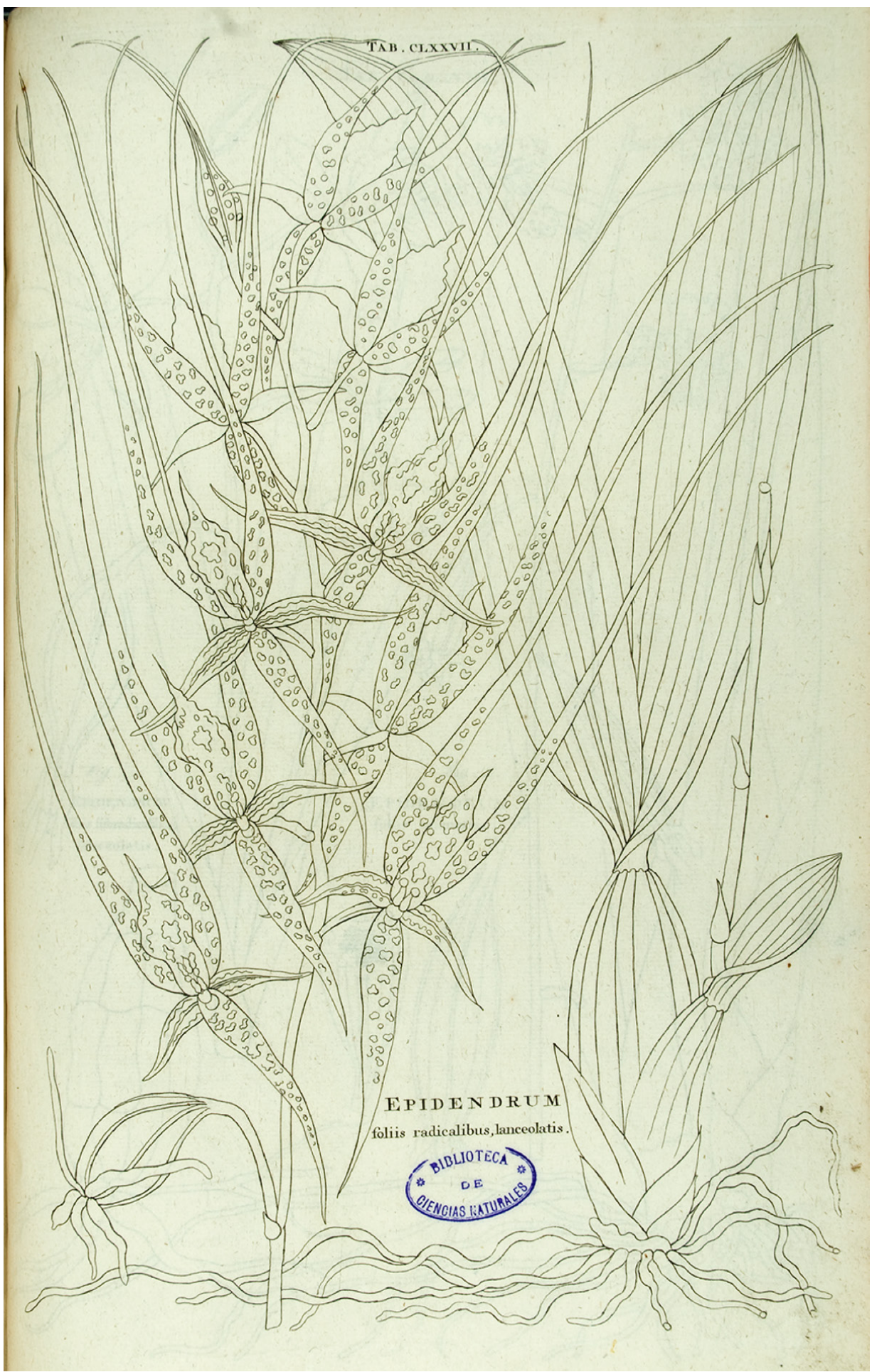

FIgURE 4. Johannes Burman's illustration of Plumier's “Epidendrum foliis radicalibus lanceolatis” (Plumier 1758), which McLeish and collaborators (1995) selected as the type for the species. 


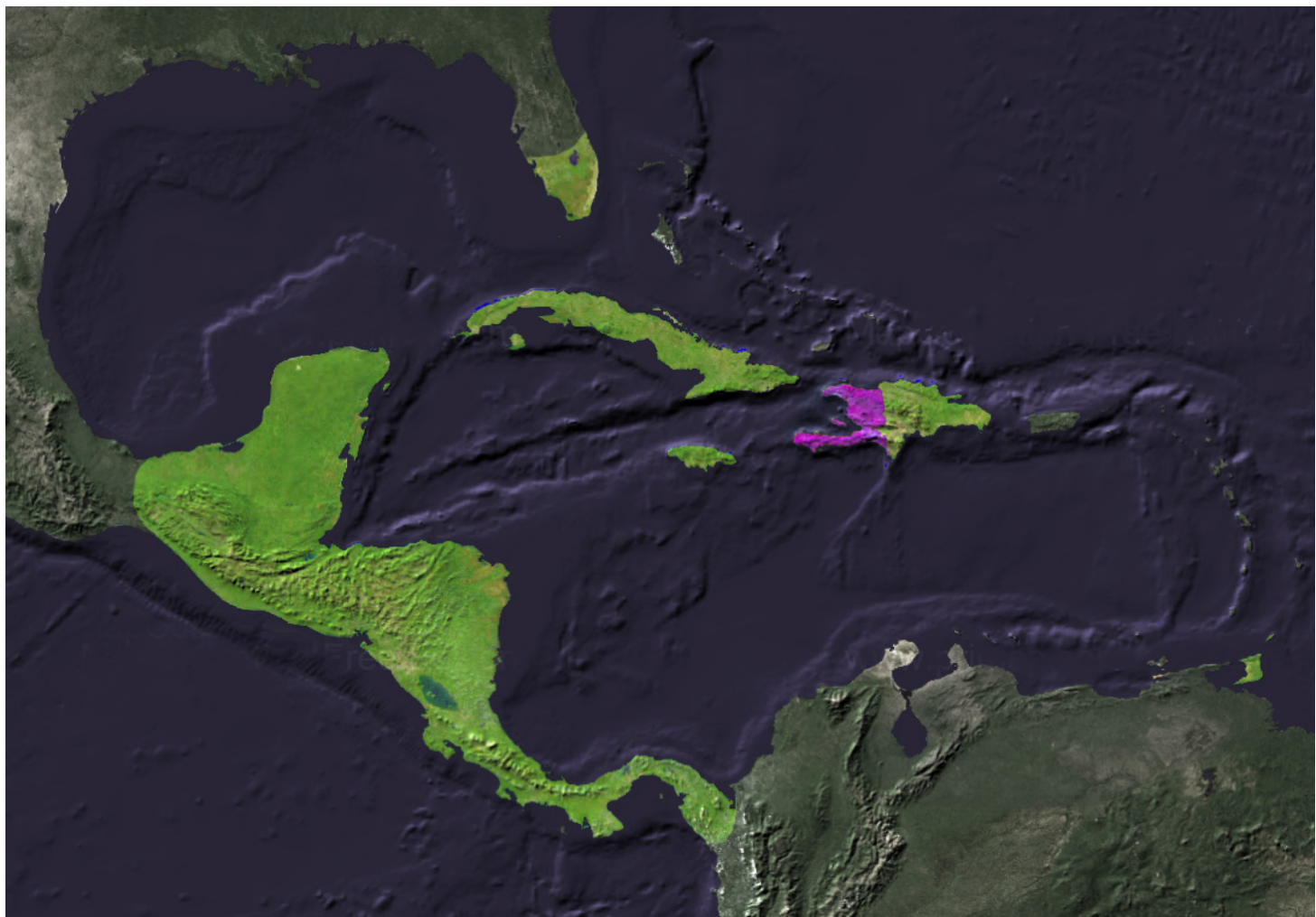

FIGURE 5. Distribution map of Brassia cf. caudata populations in Central America and the Caribbean (light green). Haiti, where Plumier botanized during his trip, is indicated in magenta.

of this poorly defined species (Atwood \& Mora 1993, Pupulin \& Bogarín 2005), and at least one of the Costa Rican taxa has been treated as the Panamanian record of B. caudata (Williams \& Allen 1946).

The name Brassia caudata is based on Linné's (1758-1759) Epidendrum caudatum, the type of which is an illustration by Johannes Burman (in Plumier 1758) (Fig. 4) from a plant traditionally treated as collected "in the West Indies." During his American trips, Plumier mostly worked in the West Indies' French dominions Haiti, Martinique and Guadaloupe - but also visited the Virgin Islands and some other islands of the Lesser Antilles, including St. Christopher, St. Croix, and the Grenadines of St. Vincent. Ackerman (2015) has recently reconsidered the actual distribution of Brassia species with caudate sepals in the West Indies and recorded it exclusively for the islands of Cuba, Jamaica, and Hispaniola (both in Haiti and the Dominican Republic) in the Greater Antilles, and the island of Trinidad in the Lesser Antilles (Fig. 5). If Burman's illustration of "Epidendrum foliis radicalibus lanceolatis" was based on a collection made by Plumier, the evidence indicates that the original specimen must have been collected in the territory of present-day Haiti. At Lankester Botanical Garden we do not have any plant of Brassia native to the island of Hispaniola, but we do grow a specimen from Jamaica, which Claude Hamilton gave to Bob Dressler many years ago (Fig. 6). The features of this plant raise the suspicion that Jamaican populations referred to B. caudata could perhaps represent a different taxon when compared to the specimen illustrated by Plumier in his "Tabula centesima septuagesima septima", or may indicate instead that more than one species of Brassia with tailed sepals inhabits the island. The only evidence available at Lankester Botanical Garden of a $B$. caudata specimen from the Greater Antilles also raises legitimate doubt about the identity of both taxa traditionally treated as $B$. caudata in Costa Rica, the correct taxonomy of other regional populations in the Central American isthmus, and the taxonomic position of the South American species included in a broad and ill-defined concept of B. caudata. 


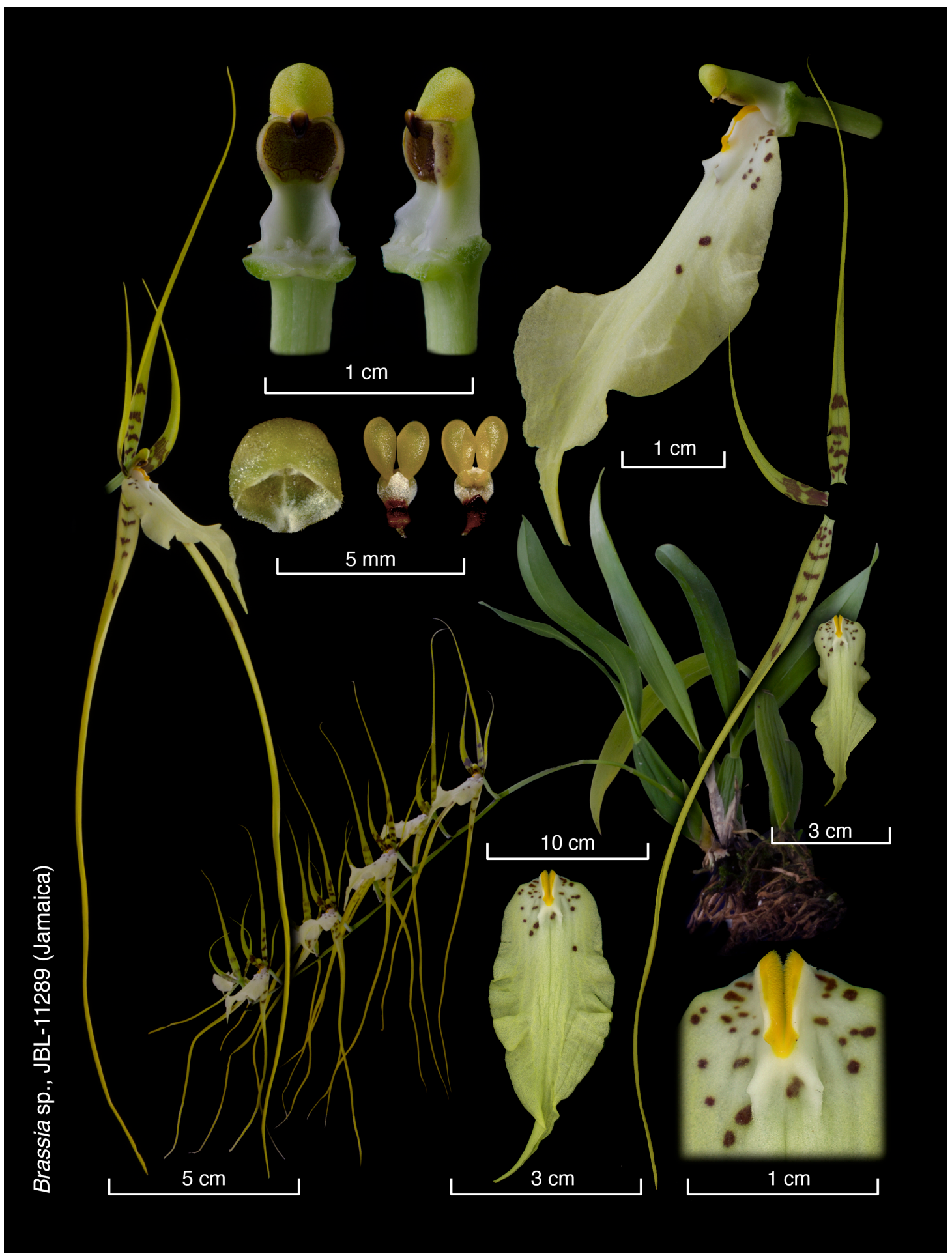

Figure 2. Lankester Composite Digital Plate of Brassia cf. caudata. Costa Rica, Caribbean morph, D. Bogarín 2553 (voucher: JBL). 
These uncertainties cannot be resolved internally in Costa Rica, nor in other continental countries in America, as the basic questions relative to the taxonomic identity of the true $B$. caudata have to be answered in the West Indies! Can a true $B$. caudata from Haiti, documented with modern imaging techniques, stand up? Can the natural variation of this species be documented and estimated at the type locality? Can the true B. caudata be compared, using similar techniques, with populations recorded from the Dominican Republic, Cuba and Jamaica? Is there a possible answer to the question about the diversity of Brassia in Jamaica and the Greater Antilles, spanning the greatly discordant morphologies of the plant collected by Plumier and the one from Jamaica grown at Lankester Botanical Garden?

It is clear that the identification of the caudate Brassia populations occurring from Mexico to Brazil and Bolivia requires a modern and integrative approach to the interpretation of the type that subtends the concept of B. caudata. It is also easy to foresee how this approach must be supported by the cooperative effort by a group of local botanists who share similar research methodologies, aimed at clarifying the status of local populations and taxa, with a preliminary emphasis on the understanding of the characteristics and range of morphological and genetic variation recorded at the type locality.

Conclusions. Just as integrative taxonomy was defined as the science aimed at delimiting the units of life's diversity from multiple perspectives (Dayrat 2005), so the integrative interpretation and the biological approach to type specimens, which incorporates complementary disciplines, are fundamentally aimed at furthering our understanding of the species concept. This integration not only allows a critical revision of the previously described species' classification, but also enhances the capacity of detecting, describing, and classifying new species in a rich biological context. The basis of the integrative study of types is not the work in the herbarium, but a complex of rigorous phenome observations that produce information of taxonomic and evolutionary value and provide a conceptual framework for the actual study of type specimens.

This methodology necessarily requires a strict local approach, which has to be mainly carried out at the type localities, as only a sharp understanding of nomenclatural types allows for a stable recognition of new phenotypes as the same as, or different from, the types of previously known taxa. After centuries of colonial botany, which in several cases had as a result a poor understanding of species boundaries and a limited appreciation of the taxonomic value of type specimens, the integrative study of types represents a powerful stimulus for cooperative research and the sharing of common methodologies.

ACKNOWLEDGMENTS. I thank my colleagues at the Lankester Botanical Garden, with whom I shared most of the concepts expressed here, and warmly acknowledge their patience in listening again and again to the topics that I summarized in this article while they gradually took shape in our discussions. A particular acknowledgment is due to Robert Dressler, who first introduced me to the idea of a biological interpretation of type specimens. The suggestions and corrections by anonymous reviewers greatly improved the manuscript.

\section{LiTERATURE CITED}

Ackerman J.D. (2015). Orchid flora of the Greater Antilles. Mem. New York Bot. Gard., 109, 1-625.

Ames B. (1947). Drawing of Florida orchids. With explanatory notes by Oakes Ames. Botanical Museum, Cambridge, Mass.

Ames O. \& Correll D.S. (1953). Orchids of Guatemala. Fieldiana, Botany, 26(2), 399-727.

Anonymous (1998a). The Global Taxonomy Initiative: shortening the distance between discovery and delivery. Environment Australia, Canberra.

Anonymous (1998b). The Global Taxonomy Initiative: using systematic inventories to meet country and regional needs. Diversitas, Systematics Agenda 2000. American Museum of Natural History, New York.

Atwood J.T. \& Mora de Retana D.E. (1999) Family \#39 Orchidaceae: Tribe Maxillarieae: subtribes Maxillariinae and Oncidiinae. Fieldiana, Botany, New Series, 40, i-vi, 1-182.

Balick M.J., Nee M.H. \& Atha D. E. (2000). Checklist of the vascular plants of Belize. Mem. New York Bot. Gard., 85, i-ix, 1-246.

Bennett D.E. Jr. \& Christenson E.A. (1995). Icones Orchidacearum Peruviarum, Volume 3. Privately published by A. Pastorelli de Bennett, Lima.

Bicudo C.E. de M. (2004). Taxonomia. Biota Neotrop., 4(1), i-ii. 
Brako L. \& Zarucchi J.L. (1993). Catalogue of the Flowering Plants and Gymnosperms of Peru. Monog. Syst. Bot. Missouri Bot. Gard., 45, i-xl, 1-1286.

Breedlove D.E. (1986). Flora de Chiapas. Listados Florísticos de México, 4, i-v, 1-246.

Briquet J., Flahault C., Harms H. \& Rendle A.B. (1906). International Rules of Botanical Nomenclature, adopted by the International Botanical Congress of Vienna, 1905. G. Fischer, Jena.

Carnevali G., J.L. Tapia-Muñoz J.L., R. Jiménez-Machorro R., L. Sánchez-Saldaña L., L. Ibarra-González L., I.M. Ramírez I.M. \& M.P. Gómez M.P. (2001). Notes on the flora of the Yucatan Peninsula II: a synopsis of the orchid flora of the Mexican Yucatan Peninsula and a tentative checklist of the Orchidaceae of the Yucatan Peninsula biotic province. Harvard Pap. Bot., 5(2), 383466.

Cogniaux, A. (1906) Orchidaceae. In: C.F.P. von Martius (ed.). Flora Brasiliensis, 3 (6). Fleischer, Leipzig.

Culley T.M. (2013). Why vouchers matter in botanical research. Appl Plant Sci., 1(11), doi: 10.3732/ apps. 1300076.

Dayrat B. (2005). Integrative taxonomy. Biol. J. Linnean Soc., 85, 407-415.

de Candolle M.A. (1867). Lois de la nomenclature botanique adoptées par le Congrès international de botanique tenu à Paris en août 1867... H. Georg, Geneva and Basel.

Dick M.H. \& Mawatari S.F. (2004). Resolving taxonomic problems of North Pacific bryozoans. Pp. 67-74 in: S.F. Mawatari \& H. Okada (eds.), Neo-science of natural history: integration of geoscience and biodiversity Studies. Proceedings of International Symposium on "Dawn of a New Natural History - Integration of Geoscience and Biodiversity Studies", March 5-6, 2004, Sapporo.

Deans A.R., Matthew J.Y. \& Balhoff J.P. (2012). Time to change how we describe biodiversity. Trends Ecol. Evol., 27(2), 78-84.

de Jong, R. (1982). The biological species concept and the aims of taxonomy. J. Res. Lepidopt., 21(4), 226-237.

Dodson C.H. (1993). Native Ecuadorian Orchids. 3. Dodson Trust, Sarasota.

Dodson C.H. \& Bennett D.E. Jr. (1989). Orchids of Peru, Icones Plantarum Tropicarum, Series 2, Fasc. 1-2, $1-200$.

Dodson C.H. \& Luer C. (2005). Orchidaceae. Genera AaCyrtidiorchis. In: G. Harling \& L. Andersson (eds.). Flora of Ecuador 76, 1-345. University of Götenborg, Riksmuseum.

Dressler R.L. (1980). Checklist of the orchids of Panama. Pp. i-xxvi in: Orchids of Panama: A facsimile reprint of the Orchidaceae, flora of Panama. Missouri Botanical Garden Press, St. Louis.
Dressler R.L. (1993). Field guide to the orchids of Costa Rica and Panama. Cornell University Press, Ithaca.

Dunsterville G.C.K. \& Garay L.A. (1966). Venezuelan Orchids Illustrated: Volume 4. Andre Deutsch, London.

Ehrlich P.R. (1961). Systematics in 1970: some unpopular predictions. Syst. Zool., 10, 157-158.

Ellison A.M, Buckley H.L., Miller T.E. \& Gotelli N.H. (2004). Morphological variation in Sarracenia purpurea (Sarraceniaceae): geographic, environmental, and taxonomic correlates. Amer. J. Bot., 91(11), 19301935.

Ellison A.M, Davis C.C., Calie P.J. \& Naczi R.F.C. (2014). Pitcher plants (Sarracenia) provide a 21st-century perspective on infraspecific ranks and interspecific hybrids: a modest proposal for appropriate recognition and usage. Syst. Bot., 39(3), 939-949.

Escobar R.R. (ed.). (1990). Orquideas nativas de Colombia. Vol. 1: Acacallis-Dryadella. Compañía Litográfica Nacional, Medellín.

Fawcett W. \& Rendle A.B. (1910). Flora of Jamaica, containing descriptions of the flowering plants known from the island. The British Museum, London.

Fernández C. (2003). Orquídeas Orquídeas nativas del Táchira. Editorial Litolifa, San Cristobal, Táchira.

Fernández E. (2007). Orquídeas de la República Dominicana y Haití / Orquídeas of the Dominican Republic and Haiti. American Chamber of Commerce of the Dominican Republic, Santo Domingo.

Flowers R.W. (2007). Comments on "Helping Solve the 'Other' Taxonomic Impediment: Completing the Eight Steps to Total Enlightenment and Taxonomic Nirvana" by Evenhuis (2007). Zootaxa, 1494, 67-68.

Foldats E. (1970). Orchidaceae. In: T. Lasser, Flora de Venezuela 15(1): 169-201. Instituto Botánico, Dirección de Recursos Renovables, Ministerio de Agricultura y Cría, Caracas.

Foster R.C. (1958). A catalogue of the ferns and flowering plants of Bolivia. Contr. Gray Herb. Harvard Univ., 184, 1-223.

Gloudon A. \& Tobisch C. (1995). Orchids of Jamaica. University of West Indies Press, Jamaica.

Graham M. (2005). The Global Taxonomic Initiative. Canad. Bot. Assoc. Bull., 38(3), 35-36.

Hamer F. (1974) Las Orquideas de El Salvador I. Ministerio de Educacion, San Salvador.

Hamer, F. (1982). Orchids of Nicaragua. Part 2. Icon. Pl. Trop., Fasc. 8, 701-800.

Jørgensen P.M. \& León-Yánez S. (eds.). (1999). Catalogue of the vascular plants of Ecuador. Monogr. Syst. Bot. Missouri Bot. Gard., 75, i-viii, 1-1182.

La Monica M. (2013). The Global Plants Initiative and JSTOR release online database for the study of plants. At: http://about.jstor.org/news, retrieved January 2016. 
Llamacho J.A. \& Larramendi J.A. (2005). The orchids of Cuba / Las orquídeas de Cuba. Greta Editores, Lleida, España.

Linné C. von (1758-1759). Systema naturae per regna tria naturae... (ed. 10). Impensis Direct. Laurentii Salvii, Stockholm.

Long R.W. \& Lakela O. (1971). A Flora of Tropical Florida. University of Miami Press, Coral Gables.

Luz J. \& Franco J. (2012). Orquídeas de Roraima. Empresa Brasiliera de Pesquisa Agropecuária, Embrapa Roraima, Ministério da Agricultura, Brasília, DF.

Martínez E., Sousa S.M. \& Ramos Álvarez C. H. (2001). Región de Calakmul, Campeche. Listados Florísticos de México, 22, 1-55.

Mather K. \& Jinks J.L. (1982). Biometrical genetics: the study of continuous variation. Third ed. Chapman and Hall, London.

McLeish I., Pearce N.R. \& Adams B. R. (1995). Native Orchids of Belize, 1-278. Balkema, Rotterdam.

McNeill J. (1976). The taxonomy and evolution of weeds. Weed Res., 16(6), 399-413.

McNeill J., Barrie F.R., Buck W.R., Demoulin V., Greuter W., Hawksworth D.L., Herendeen P.S., Knapp S., Marhold K., Prado J., Prud'homme van Reine W.F., Smith G.F., Wiersema J.H. \& Turland N.J. (2011). International Code of Nomenclature for algae, fungi, and plants (Melbourne Code), adopted by the Eighteenth International Botanical Congress, Melbourne, Australia, July 2011. Regnum Veg., 154 [Appendices II-VIII in Regnum Veg. 157].

Misas Urreta, G. (2006). Orquídeas de la Serranía del Baudó, Chocó, Colombia / Orchids from the Serranía del Baudó, Chocó, Colombia. Corporación Capitalina de Orquideología, Bogotá.

Mújica Benítez E., Pérez Márquez R., Bocourt Vigil J.L., López Trabanco P.J. \& Ramos Calderón T.M. (2000). Géneros de orquídeas cubanas. Editorial Félix Varela, La Habana.

Nir, M. A. (2000). Orchidaceae Antillanae. DAG Media Publishing, Inc., New York.

Ospina H.M. (2008). Las orquídeas Oncidiineas de Colombia / The Colombian Oncidiinae orchids. Ediciones Ántropos, Bogotá.

Padial J.M., Miralles A., De la Riva I. \& Vences M. (2010) The integrative future of taxonomy. Front. Zool., 7, $1-16$,

Patterson, D.J., Cooper J., Kirk P.M., Pyle R.L. \& Remsen D.P. (2010). Names are key to the big new biology. Trends Ecol. Evol. 25, 686-691.

Plumier C. (1758). Plantarum americanarum fasciculi decem, continentes plantas, quas olim... Sumtibus Auctoris, Prostant Amstelædami [Amsterdam] in Horto Medico, Atque apud Petrum Schouten, \& apud Gerard. Potvliet, \& Theodor. Haak., Leiden.
Pupulin F. (2005). Vanishing Beauty. Vol. 1: AciantheraKegeliella. Editorial de la Universidad de Costa Rica, San José.

Pupulin F. (2013). Toward a global orchid taxonomic network. Lankesteriana, 13(1-2), 75-91.

Pupulin F. \& Bogarín D. (2005). The genus Brassia in Costa Rica: a survey of four species and a new species. Lindleyana in Orchids (Bull. Amer. Orch. Soc.), 74(3), 202-207.

Rakosy D., Speckmaier M., Weber A., Huber W. \& Weissenhofer A. (eds.). (2013). Orchids. Botanical jewels of the Golfo Dulce Region, Costa Rica. Verein zur Förderung der Tropenstation La Gamba, Vienna.

Rodríguez Caballero R.L., Mora D.E., Barahona M.E. \& Williams N.H. (1986). Géneros de Orquídeas de Costa Rica. Editorial Universidad de Costa Rica, San José.

Schweinfurth C. (1961). Orchids of Peru. Fieldiana, Botany, 30(4), 787-1005.

Schultes R.E. (1960). Native Orchids of Trinidad and Tobago. Pergamon Press, New York.

Staats M., Erkens R.H.J. van de Vossenberg B., Wieringa J.J., Kraaijeveld K., Stielow B., Geml J., Richardson J.E. \& Bakker F.T. (2013). Genomic treasure troves: complete genome sequencing of herbarium and insect museum specimens. PlosOne 8(7): e69189. doi:10.1371/journal. pone. 0069189

Stevens W.D., Ulloa U.C., Pool A. \& Montiel O.M. (2001). Flora de Nicaragua. Monogr. Syst. Bot. Missouri Bot. Gard., 85, i-xlii, 1-2666.

Steyermark J.A., Berry P.E. \& Holst B.K. (eds). Flora of Venezuelan Guayana, vol. 7. Missouri Botanical Garden Press and Timber Press, St. Louis and Portland.

Straub S.C.K., Parks M., Weitemeir K., Fishbein M., Cronn R. \& Lston A. (2012). Navigating the tip of the genomic iceberg: next-generation sequencing for plant systematics. Am. J. Bot. 99: 349-364.

Vásquez R. \& Dodson C. H. (1982). Orchids of Bolivia. Icones Plantarum Tropicarum, Series 1, Fasc. 6, 501600 .

Williams L.O. \& Allen P. H. (1946). Orchidaceae. In: R.E. Woodson, Jr. \& R.W. Schery. Flora of Panama. Part III, Fascicle 4. Ann. Missouri Bot. Gard., 36.

Werkhoven M.C.M. (1986). Orchideeen van Suriname / Orchids of Suriname. Vaco, Uitgeversmaatschappij, Paramaribo.

Wilson E. (2003). The encyclopedia of life. Trends Ecol. Evol., 18, 77-80.

Wunderlin R.P. (1998). Guide to the vascular plants of Florida. University Presses of Florida, Tampa.

Zelenko H. \& Bermúdez P. (2009). Orchids Species of Peru. Zai Publications, Quito. 
LANKESTERIANA • V SCIENTIFIC CONFERENCE ON ANDEAN ORCHIDS 